\title{
Vocatives in the Balkans
}

\author{
Vocativos em línguas balcânicas
}

Virginia Hill

\begin{abstract}
This paper argues that: (i) vocative nouns project beyond DP, to a VocP level that maps the basic pragmatic features involved in the derivation of nominal expressions conveying a direct address; (ii) this pattern can be generalized crosslinguistically; (iii) variations within this pattern are predictable in a principled way, and one particular example arises in the case of reverse vocatives; (iv) reverse vocatives are really restricted in a way that indicates a particular language contact situation.
\end{abstract}

Key words: vocatives; speech acts; language contact.

\section{Resumo}

Neste artigo, argumenta-se que: (i) nomes que funcionam como vocativos têm uma estrutura sintática que vai além do nível DP, incluindo uma projeção VocP, camada responsável pelo mapeamento de traços pragmáticos básicos envolvidos na derivação de expressões nominais que veiculam um tratamento direto; (ii) esse padrão pode ser generalizado translinguisticamente; (iii) variações dentro desse padrão são previsíveis e um exemplo particular surge no caso de vocativos reversos; (iv) vocativos reversos são restritos de tal forma que indica uma situação particular de contato de línguas.

Palavras-chave: vocativos; atos de fala; contato de linguas.

^ University of New Brunswick 


\section{Introduction}

7 his paper aims to show that the pan-Balkan particle bre/vre, dedicated to the marking of the addressee, is instrumental for discovering the internal structure of a vocative phrase, and that language contact in the Balkans (and beyond) concerns not only the lexical borrowing of bre/vre, but also the borrowing of a syntactic pattern for deriving reverse vocatives. More precisely, while bre/vre leads us to a configuration that applies cross-linguistically for the derivation of a regular vocative phrase, certain variations within this pattern (namely, the reverse vocatives) are restricted to a group of Balkan languages that involve both Romance and Slavic dialects. This areal restriction indicates a language contact borrowing of a syntactic (versus lexical) nature.

\subsection{Data}

This paper focuses on Romanian and Greek vocative phrases, such as in (1), which display the particle bre/vre on an optional basis.

(1) a. (Bre) mamaie, te rog eu să mergi la doctor. Rom BRE gran'ma.VOC you beseech I SUBJ go.2SG to doctor 'Gran'ma, I implore you to go to the doctor.'

Revista Letras,

Curitiba, UFPR, n. 96 , pp.334-353, jul./dez. 2017. ISSN 2236-0999 (versão eletrônica) 
b. (Vre) jaja, ti kanis eki?

BRE gran'ma what do there

'Gran'ma, what are you doing there?'

The first observation is that, although the particles bre/vre are classified as interjections in traditional grammar (i.e., particles without morpho-syntactic import), they exhibit syntactic restrictions in their distribution in relation to the vocative noun. For example, they require adjacency to the vocative phrase, as in (2), where the intervening element rules out the construction.
a.
Bre (`la doctor) mamaie,
te $\operatorname{rog}$ să mergi.
Rom
BRE at doctor gran'ma-VOC you beseech SUBJ go.2SG
Intended: 'To the doctor, gran'ma, I implore you to go there.'
b. Vre ("${ }^{\star}$ avrio) jaja ti kanis?
BRE tomorrow gran'ma what do
Intended: 'Gran'ma, what are you doing tomorrow?'

In the absence of bre/vre, the fronting of the constituents marked with * in (2) yields grammatical sentences. The problem arises only from their placement between the vocative particle and the vocative noun. This effect is not expected of an item that is supposed to be inserted only in the phonological component. Thus, the first question is: what can the behaviour of bre/vre tell us about the syntax of the vocative phrase?

The second observation is that there is variation in the internal structure of Romanian vocative phrases that yields reverse vocatives, as in (3). These vocative phrases contain both the addressee and the speaker in the address phrase. The reference for the speaker is a kin term, and the pragmatic reading is that the kin member has the authority to ask or advise the addressee by virtue of their relation.
Gabi mamă, du-te
la doctor!
Romanian
Gabi mother go-REFL to doctor
'Gabi, go to the doctor (I, the mother, tell you)'

Thus, the second question is: how do reverse vocatives compare with regular vocatives?

Finally, reverse vocatives occur in a handful of Balkan languages that may be genetically unrelated or even outside the Balkan area (see also Iovino (2013) for Southern Italian dialects). Hence, the third question is: why do reverse vocatives appear in these particular languages but not in the entire Balkan area?

These questions will be approached in the generative grammar framework presented in Section 2. In a nutshell, we are looking at the structure 
V. HiLl

Vocatives in the Balkans

of Determiner Phrases (DP) within the vocative phrase, and at the parametric settings that led to the option for reverse vocatives.

\section{Theoretical framework}

One highly debated issue in generative grammar nowadays is whether conversational pragmatics has anything to do with syntax (e.g., FOLLI; TRUSWELL; SEVDALI, 2013); and if it does, to what extent that may be, and how would a syntax of conversation look like (e.g., HAEGEMAN; HILL, 2014)? There are many studies showing that choices made at the level of conversational pragmatics coincide with restrictions in the derivation of clauses, entailing that the derivation computes what we consider pragmatic features before it reaches the interfaces (e. g., ROSS, 1970; OYHARÇABAL, 1993; CINQUE, 1999; SPEAS; TENNY, 2003; MUNARO; POLETTO, 2004; SPEAS, 2004; TENNY, 2006; SIGURDSSON, 2004; 2008; 2011; ZANUTTINI, 2008; GIORGI, 2010; KIDWAI, 2010; ZU, 2011; MIYAGAWA, 2012; STAVROU, 2014).

The most influential formalization in this respect comes from Speas and Tenny (2003).

In this proposal, the pragmatic features are mapped independently to syntax and, due to their intrinsic scopal properties, they have been situated at the highest level of the left periphery. The hierarchy in (4) has been adjusted according to more recent improvements brought to the initial proposal, and summarizes the results of their study.

(4)

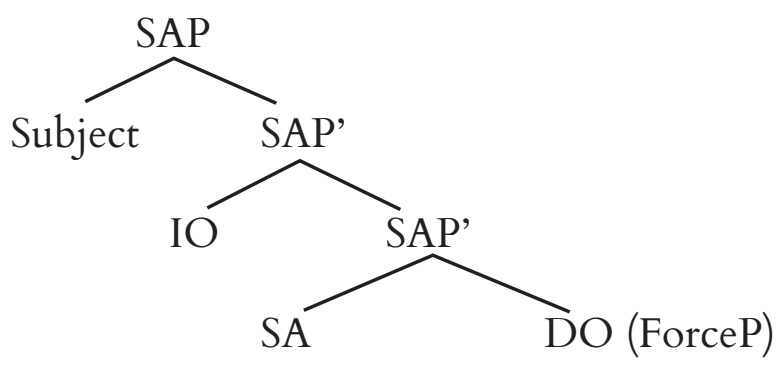

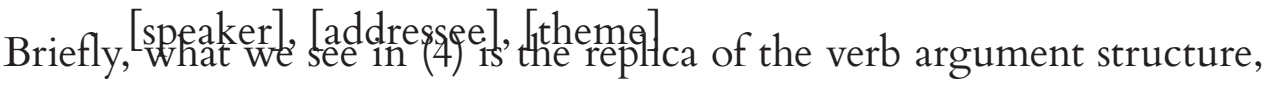
where the head is the speech act instead of the verb. More precisely, the pragmatic role features of 'speaker' and 'addressee' correlate to the speech act in the same way 'agent' and 'patient' correlate to the thematic grid of a verb, and have the same syntactic effects by being merged as subject or (direct/indirect) objects. Hence, if we have evidence for speaker and addressee as being functional features, it must also be the case that the speech act feature is mapped to syntax as a "verby" functional feature that constrains the performativity typing. The crucial property of (4) is that it is projected at the left periphery of the CP field, and thus,

Revista Letras,

Curitiba, UFPR, n. 96, pp.334-353, jul./dez. 2017. ISSN 2236-0999 (versão eletrônica) 
it belongs to the functional domain of the matrix clause. That is, (4) involves a mono-clausal structure and thus, it avoids the pitfalls of the bi-clausal structure (the performativity hypothesis) proposed for similar phenomena in Ross (1970).

As vocatives are expressions of direct adress, they belong to the type of data covered by the representation in (4). In fact, Hill (2014) argues that vocative phrases merge as indirect objects in a structure like (4). In this paper, however, the focus is not on the position of the vocative phrase in the clause, but on the internal structure of such a phrase; that is, the structure that allows for the presence of bre/vre in a way that it requires adjacency to the vocative noun. In this respect, the studies mentioned above and especially the possibility of generating (4) provide the necessary theoretical tools for dealing with the mapping of the pragmatic features. More precisely, under the assumption that CPs and DPs equally map discourse features at their left periphery (see Aboh (2004) and references within; also Wiltschko (2014) for a different approach), it is predictable that vocative phrases consist of DPs that substantiate such an extension of their functional field. We shall argue that this existention consists of a Vocative Phrase (VocP).

\section{The syntactic status of BRE}

Vocative particles such as bre/vre define the inter-personal relation between the speaker and the addressee - whether this relation is formal or informal, with further nuances of (in)formality depending on their position in the clause or around the noun, as well as the type of communication (command, negotiation, pleading etc.). These particles are cross-linguistically used, some on an optional basis, others as obligatory markers of vocatives (see a list in Hill (2014)). These particles are independent of the Vocative Case morphology, with which they may co-occur.

The main property of vocative particles is their intrinsic addressee feature, which makes them compatible only with vocatives and not with nouns elsewhere. Among them, bre is a pan-Balkan particle that optionally occurs in front of vocative nouns or it may be used by itself as an attention drawer or a form of address. It displays variations from one language to another or within the same language. For example, Joseph (1997) counts 56 versions of bre/more in Greek (see also Tsoulas and Alexiadou (2005)). The absence of this vocative particle automatically signals an underspecified degree of formality (neutral politeness), instead of familiarity.

(5) a. Bre (mamaie), te rog eu să mergi la doctor. Rom BRE gran'ma-VOC you beseech I SUBJ go.2SG to doctor 'Gran'ma, please go to the doctor.' 
b. Vre (jaja), ti kanis eki?

Greek

BRE gran'ma what do there

'Gran'ma, what are you doing there?'

So far, BRE has been treated as an interjection with no relation to grammar. However, the following tests of distribution and constituency indicate that BRE is computed in the derivation of the vocative phrase.

BRE is a Main Clause Phenomenon

On a par with any vocative phrase, BRE cannot occur at the left periphery of a subordinated clause. Consider the examples in (6) and (7).

(6) a. (ee) ipe oti (ee) ine etimos (ee) na petaksi (ee) sti Xavai.

Rom

INT said that INT is ready INT SUBJ fly INT to.the Hawai

'Hmm, he said that he is ready to fly off to Hawai!'

b. $\quad(M d a)$, zicea (mda) că, (mda) în fine, (mda) ar vrea

Greek

INT said INT that INT in end INT would want

(mda) să cumpere casa.

INT SUBJ buy house-the

'Hm, he said that, finally, he would like to buy the house.'

(7) a. (Vre Maria), o Petros ipe oti, ( ${ }^{\star}$ vre Maria), den bori na erthi avrio. Rom BRE Maria the Petros said that BRE Maria not can SUBJ come tomorrow. 'Maria, Petros said that he cannot come tomorrow.'

b. (Bre), zice că ( ${ }^{\star}$ bre) ar vrea să cumpere casa.

BRE says that BRE would want SUBJ buy house-the

'Hey man, he said he would like to buy the house.'

The word order in (6) indicates that interjections may occur anywhere in-between constituents, including the embedded clause. By contrast, in (7), BRE is possible only in matrix clauses: there are positions from which BRE is excluded, and even when it occurs in sentence final position, it is still interpreted as having scope over the entire utterance. There is never the case that, in constructions as in (7) BRE may be interpreted only in relation to the embedded clause.

\section{- Obligatory adjacency}

The examples in (2) showed that fronted constituents cannot separate BRE from the vocative noun. The examples in (8) further show that interjections meet with the same restrictions. 
(8)

a. Ee, vre ( ${ }^{*}$ ee) Maria den katalavenis tipota pia! Greek INT vre INT Maria.VOC not understand nothing anymore 'Eh, vre Maria, you understand nothing any longer!'

b. (Mda) bre ( $\left.{ }^{*} \mathrm{mda}\right)$ Ioane, unde te duci? Rom INT bre INT Ion-VOC where REFL go-2SG

'Hm, John, man, where do you go?'

The examples in (6) show that interjections can occur anywhere in-between constituents. Thus, the fact that they are disallowed between BRE and the vocative noun in (8) indicates that BRE is computed together with the vocative noun as a constituent.

\section{- BRE c-commands the nominal phrase in vocatives}

The word order between BRE and noun is restricted: if BRE is a free morpheme, as in Greek and Romanian, it can only precede the noun (9); if it is a bound morpheme, as in Bulgarian, it can only encliticize on the noun. This indicates that BRE selects the vocative noun phrase, which can either stay in situ, in a complement position or move to a Specifier related to the selector BRE. Note that this assessment applies to BRE-vocative phrases that form a prosodic unit (i.e., there is only one high pitch for the unit). If the intonation relies on two high pitches (i.e., one for BRE, one for the vocative phrase), then we deal with repeated vocatives (i.e., separate prosodic units), which are not relevant to the discussion.

(9) a. Re pedja, ti ine afta?! VERSUS ${ }^{\star}$ Pedja re, ...

Greek

RE kids, what are these?

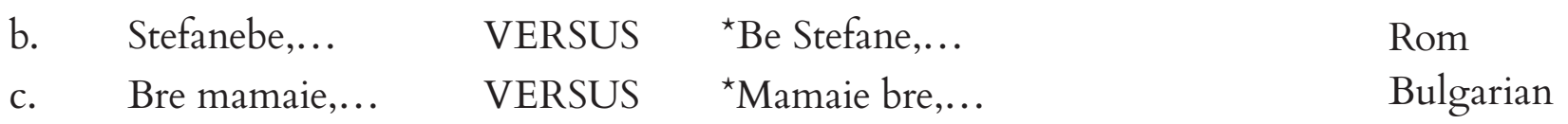

Further evidence for the c-command position of BRE comes from coordination, as in (10): BRE selects the Coordination Phrase containing the two noun phrases, since it cannot be repeated on the second constituents.

(10) a. Vre Maria ke ( ${ }^{\star}$ vre $) \quad$ Kosta....

Greek

VRE Maria and VRE Kosta...

Rom

b. Bre tată şi ( ${ }^{\star}$ bre) unchişorule,....

BRE father and BRE uncle.the.VOC

'Father and uncle,....'

c. Bre majko i ( ${ }^{\star}$ bre $)$ leljo,...

Bulgarian

BRE mother.VOC and BRE aunt-VOC

'Mom and aunty,...'

Cross-linguistic counterparts of BRE 
V. HiLl

Vocatives in the Balkans

In some Bantu languages, the presence of the vocative particle is obligatory for the noun to be interpreted as a vocative, as in (11) for the Setswana enclitic particle -a (JANSON, 2013, p. 227).
a. mogatsake > vocative: mogatsaka my husband
b. mme > vocative: mma mother

There is no doubt that such particles must be present during the syntactic derivation or else the vocative cannot arrive in the right position at the interface (i.e., it should be left out of the thematic grid of the verb).

In sum, the data in (5) to (11) allow us to conclude that the vocative particle (be it BRE or its counterparts) is syntactically computed in the derivation of the vocative phrase: it is either the selector of the relevant nominal phrase, or is in a local relation with the element that selects that nominal phrase.

\section{Functional features}

The definition of BRE as a syntactic item entails a justification in terms of feature checking mechanisms that govern any syntactic derivation. The data presented in this section indicate that these features concern the inter-personal relation between the speaker and the addressee, as well as the validation of the vocative DP as being the reference for the addressee (i.e., the 2 nd person).

\subsection{The inter-personal [i-p] feature}

While vocative phrases may be derived without BRE, the addition of BRE contributes information on the interpersonal relation between the speaker and the addressee. This is an outstanding property that affects the syntactic derivation since it may decide on whether the particle is optional or obligatory in vocative phrases. More precisely, BRE and other equivalent vocative particles (e.g., Romanian măi) are optional in Balkan languages, but their counterparts could be obligatory with formal addresses in other languages, such as the enclitic -umma in the Arab of the Koran (http://corpus.quran.com/documentation/ vocative.jsp).

One may argue that the association between the [i-p] feature and a particle like BRE arises purely from the lexical entry, and becomes part of the compositional meaning of the sentence post-syntax, without involving syntactic processing. However, there are strong arguments against such an approach,

Revista Letras,

Curitiba, UFPR, n. 96, pp.334-353, jul./dez. 2017. ISSN 2236-0999 (versão eletrônica) 
concerning agreement, the placement of the definite article and the use of the morphological Vocative Case.

\section{- Agreement effects}

Romanian fă and Bulgarian ma, which are strong indicators of a degraded inter-personal relation, are compatible only with feminine singular nouns used as vocatives (i.e., 2nd person), and rule out any other combinations. The selected noun has to conform to the grammatical gender of the particle. This matching must take place before the derivation is sent to the interfaces, because agreement is a morpho-syntactic operation.

\section{- Vocative Case}

The second argument is that the [i-p] feature is not unique to vocative particles, since it can also be conveyed differently, e.g., through Vocative Case marking only, as in (12).
a. măi Radu, ... = informal
mai Radu
b. $\quad$ Radule, $\ldots=$ informal
Radu.the.voc
c. $\operatorname{Radu}, \ldots .$. formal

The informality of the address in (12) comes not only from the use of the particle in (12a), but also in the absence of the particle, from the option for a noun form with Vocative Case marking, in (12b). Lack of Vocative Case marking yields a neutral or formal address in (12c). Vocative Case is not obligatory on vocative nouns in Romanian. Therefore, the [i-p] feature is a property of the vocative phrase, not only of the particle, and its informal value can be checked in two ways:

[i-p] is mapped through

(i) particle merge or

(ii) Vocative Case marking

Greek, in contrast, has obligatory Case marking (although this may not be always visible due to the existence of case syncretism in the modern language), so these endings are irrelevant for discourse features. The point is that the [i-p] feature is a functional feature, and the way it is checked and valued may vary intra- and cross-linguistically, the insertion of the vocative particle being only one option for implementing this process in some languages. 


\section{- The definite article}

Romanian vocative nouns display definite articles on an optional basis. The presence of the definite article indicates N-to-D (GIUSTI, 1993; 2005). However, the presence or absence of the article is not related to definiteness (the addressee being referenced, hence it has inherent definiteness), but to the interpersonal relation. For example, the presence of the article without Vocative Case ending in (14a) indicates a respectful address to an inferior party (e.g., a waiter) while the absence of the article in (14b) indicates a condescending address to a minor. A version like in (14c), where the inter-personal feature is not indicated, neither through the article nor the vocative particle, is ungrammatical as a direct address with this noun.

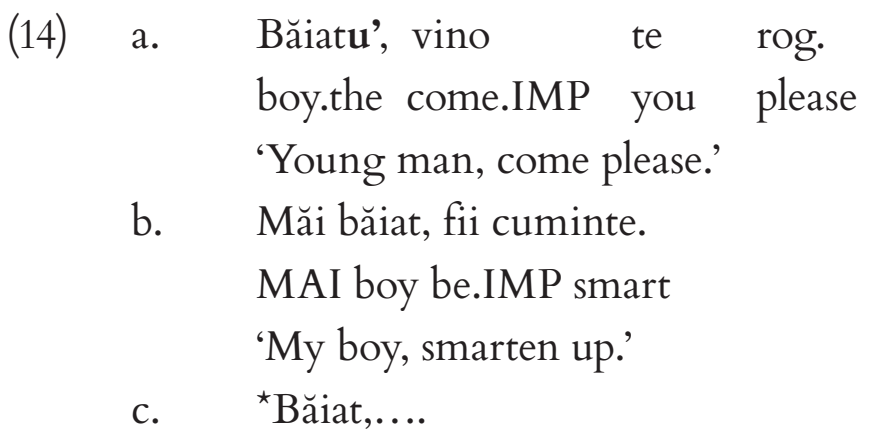

The point is that the choice between having or not having the article in $\mathrm{D}$ must be made during the syntactic derivation. Since this choice depends on the intended value for the $[\mathrm{i}-\mathrm{p}]$ feature, this feature must be present in the computation.

To conclude, the $[i-p]$ feature is a property of the vocative phrase, and it may be checked by a particle like BRE, or by Vocative Case marking, or by the manipulation of the definite article, or a combination of the above. Hence, the [i-p] feature must be mapped onto a functional head that derives the vocative phrase. If the option goes for BRE, then BRE checks and values [i-p] through direct merge, by virtue of its semantics.

\subsection{The [2nd] person feature}

Any vocative, including those preceded by BRE, restricts the interpretation of the noun to the second person, since it stands for the identification of the addressee. The question arises again whether the second person interpretation arises from the semantics or from the syntax of vocative phrases. This is especially ambiguous for BRE, because this item is intrinsically (i.e., lexically) specified for the 2 nd person.

There is clear evidence for the presence of a [2nd] person feature in the functional domain of the vocative noun. Theoretically, D is associated with

Revista Letras,

Curitiba, UfPR, n. 96, pp.334-353,

jul./dez. 2017. ISSN 2236-0999 (versão eletrônica) 
[person] in many studies on noun structure, for nouns distributed inside the clause (HARLEY; RITTER, 2002; inter alia). This association can be naturally extended to vocative phrases. Empirically, such an approach can be supported by data as in (15), where the vocative noun is interpreted as having a [2nd] person irrespective of whether BRE is present or not. More precisely, with regular DPs, co-reference relations can be established between a fronted common noun and a personal pronoun only for the [3rd] person, as in (15b); however, when the clause initial noun is a vocative, as in (15a), co-reference is only possible with [2nd] person pronouns. The same restriction applies in Romanian (and any other language), as in (15c).

(15) a. Guysi, can youi $/{ }^{\star} k$ believe themk $/{ }^{\star} \mathrm{i}$ ?

b. The guysk, can youi $/{ }^{\star} \mathrm{k}$ believe themk $/{ }^{\star}$ i?

c. Fetelej, lek $/^{\star} \mathrm{j}$ mai putețij/ ${ }^{\star} \mathrm{k}$ crede?

girls.the them more can.2PL believe

'The girls/Girls, can you believe them?'

The co-reference contrast illustrated in (15) comes from the fact that vocative nouns have an obligatory [2nd] person (an observation dating back to Fink 1972), whereas nouns used elsewhere have a [3rd] person feature by default (e.g., BERNSTEIN, 2008a, b).

These facts have been already noticed in the literature, and the ensuing question concerned the mechanism responsible for the change in the value of the person feature according to whether the noun is a vocative or not. Bernstein 344 (2008a, b) argues that the person feature is mapped to D and it is valued as a [3rd] person on common nouns. In order for such a noun to obtain a [2nd] person feature, D should be eliminated. In light of the examples provided here, we can nuance that and say that $\mathrm{D}$ could be eliminated, but also, it could be associated with a different feature set. This explains why definite articles (i.e., the spellout for D) are eliminated from vocatives in some languages (e.g., English, Greek) but may appear in other languages (e.g., Bulgarian, Romanian) on the condition that they check other features, not the person feature. Indeed, we had examples such as (14a) and (12b), where the article was shown to check the [i-p] feature, not the person feature. That, however, means that we still do not know where the person feature is mapped in the vocative phrase, and how it is checked and valued. The only clarification is that $\mathrm{D}$ is not associated with the person feature in these constructions.

Casting this discussion in a perspective where BRE is a syntactic item merged in vocative phrases, we can now pinpoint that BRE has an intrinsic [2nd] person feature, and that it can check and value this feature within the functional projection it is merged in. This functional projection also contains the [i-p] feature, which can also be checked and valued by BRE. Moreover, we 
V. HiLl

Vocatives in the Balkans

know that the functional head associated with these two features cannot be D. Thus, we reach the conclusion that there is a further functional projection in the extended domain of $\mathrm{N}$, projected only when these two features are included in the Numeration. We label this projection as VocP.

\section{VocP}

The data discussed so far helped us to identify the existence of VocP due to the properties of the vocative particle. However, the vocative particle is optional, whereas the vocative readings constantly rely on the checking of [i-p] and [2nd] person. It follows that VocP is constantly present in the structure of a vocative phrase, irrespective of whether it has a lexical implementation or not. Thus, we propose the representation in (16) as underlying any vocative phrase, cross-linguistically.

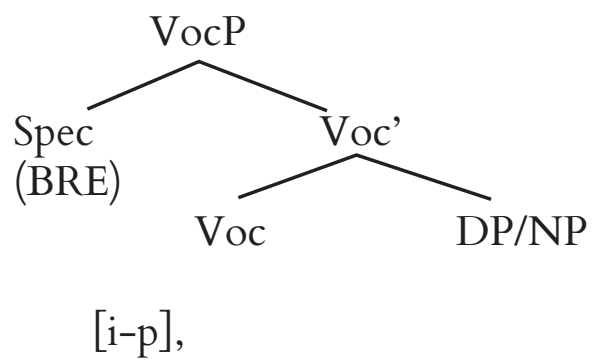

The main point is that, although BRE helped us to establish the derivation in (16), this structure is universal and does not depend on the presence of BRE or another particle. The inference is that the features of Voc are checked either by merging a dedicated particle like BRE or by movement, which could be either $\mathrm{XP}$ movement to the Spec, VocP or head movement to Voc. There is much crosslinguistic variation in this respect within the Balkan language group (see Hill (2014) for intra- and cross-linguistic variations in the options for implementing (16)).

The two features of Voc entail other featural components that restrict the selection and the derivation of the phrase. For example, [i-p] entails that VocP is an entity (i.e., another person, an addressee) not an event. Hence the selection is restricted to items with the categorial feature $[\mathrm{N}]$ (nouns, pronouns, nominalized adjectives). On the other hand, [2nd] entails that Voc takes over the function of $\mathrm{D}$, so nouns can be checked for person directly against Voc instead of D.

Although we will not go into the details of the cross-linguistic variation here, we will point out what this proposal means for the debate in the literature on whether vocative phrases are DPs (CRISMA, 1997; D'HULST et al., 2007) or NPs (LONGOBARDI, 1994). According to (16), both configurations occur, even in the same language. Greek, for example, eliminates the article and is

Revista Letras,

Curitiba, UFPR, n. 96 , pp.334-353, jul./dez. 2017. ISSN 2236-0999 (versão eletrônica) 
systematically VocP > NP when the noun has no modification or is modified by an attributive adjective, as in (17a); feature checking takes place by $\mathrm{N}$-to-Voc. However, if the vocative is a nominalized adjective or a noun modified by a possessive, as in (17b) (i.e., derivations that obligatorily involve the DP layer), the derivation is VocP > DP, the definite article is present (within DP), and feature checking involves DP-to-Spec, VocP or distance Agree.

(17) a. $\quad\left({ }^{\star} \mathrm{I}\right)$ fitites, iste poli aprosekti!

the students are very careless

'Students, you are very careless!'

$\begin{array}{ll}\text { b. } \quad \text { Tu patera } & \text { su je! } \\ \text { the father.gen } & \text { your son } \\ \text { 'Your father's son!' } & \end{array}$

In conclusion, the representation in (16) relies on the option in grammar, in general, for mapping pragmatic features to syntax, which is systematically implemented at the left periphery of phases (CP, DP, vP etc.). In this vein, $\mathrm{VocP}$ in (16) is predictable. Although the number of features mapped to Voc is reduced (i.e., [i-p] and [2nd]), the number of derivational variations is considerable, due to the options that are generally available for feature checking and valuation (i.e., first or second merge; phrase or head movement; recycling of $\mathrm{D}$ or its elimination). The cross-linguistic variation we see in the vocative phrases follows from this array of derivational options within the pattern in (16), which remains constant.

\section{Reverse vocatives}

Vocative phrases in Balkan languages, including Romanian, follow the pattern in (16). However, some of these languages display the possibility of a more complex structure than the one generated in (16). In particular, the vocative phrase may contain not only the addressee but also the speaker of the utterance. These are labeled reverse vocatives (following Rieschild (1998)) and are illustrated in (18) for Romanian.

(18) a. (Măi) Dane mamă, un' te duci?

MAI Dan.voc mother where refl go.2sg

'Dan, where are you going?'

b. `Mamă Dane, un' te duci?

mother Dan.voc where refl go.2sg

In (18), the vocative seems to occur in doubles: once it has the hearer Dane as the addressee; once it has the speaker mamă 'mother' as injunction in relation 
V. HiLl

Vocatives in the Balkans

to the addressee. Crucially, the complex addressee+speaker form a single prosodic unit, with the high pitch on the addressee. In addition, the vocative particle măi (functionally equivalent to BRE) is optional, and always modifies the addressee, within the same prosodic unit. The noun mamă 'mother' refers to the speaker, and establishes a kinship relation between the interlocutor and the speaker. This interpretation does not allow us to classify 'mother' as an exclamation (i.e., nonaddress), since it fully identifies the participant (it has reference) versus the generic use of 'mother' in an exclamation, for the general purpose of complaining. Thus, by interpretation and form (i.e., noun stem without article), this noun qualifies as a vocative. The kinship noun reverses the vocative role in the conversation by switching the focus of identification from the interlocutor back to the speaker.

The first observation is that the nouns that can identify the speaker are all kinship nouns, showing a constraint on the lexical choice. Hence, the pragmatic goal of these forms is to establish the authority on which a request is made. A semantic constraint on the nouns that qualify as addressee in these constructions is also expected, since it has to be compatible with the kinship relation (they are, by default, names of the kin referents). Second, the word order between the addressee and the identified speaker is fixed: the addressee must precede the reverse vocative or else ungrammaticality ensues as in (18b).

Since functional projections are the medium by which the discourse features of the Numeration are introduced and licensed in the syntactic structure, the analysis of reverse vocatives must focus on identifying the functional features involved. According to the interpretation, namely, the obligatory kinship property of the speaker, which is a marked [i-p] value, we propose that the features of Voc are mapped separately (instead of being clustered). In other words, VocP can have a finer-grained structure, as shown in (19). The order of the functional projections in (19) is established according to the restrictions of word order, which always displays the addressee above the kinship noun (see (18b)) in linearizations.

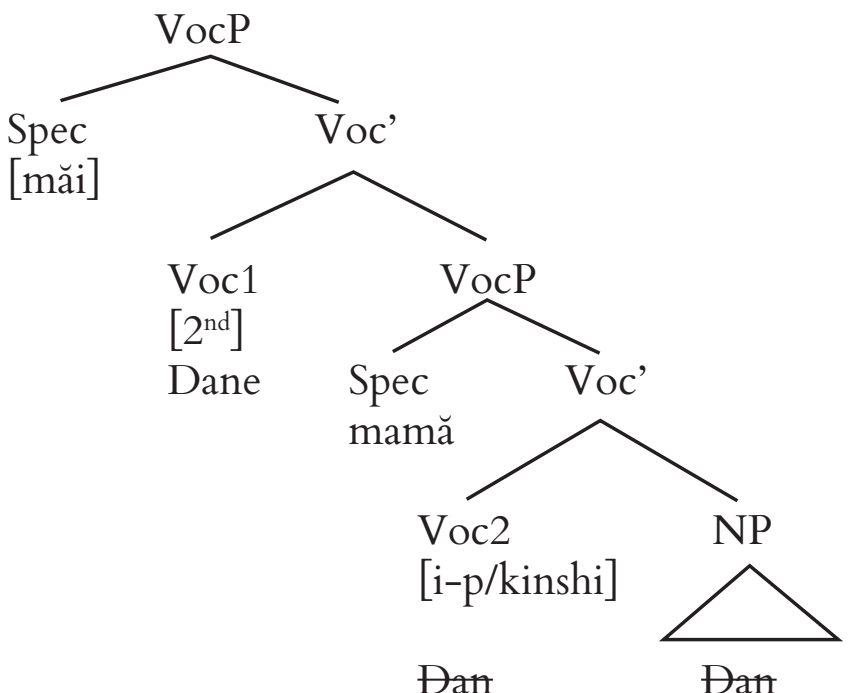

Revista Letras, 
In (19), the [2nd] person and the [i-p] features are mapped to separate heads, instead of being syncretic on Voc. This occurs when the [i-p] comes valued as 'kinship' instead of being underspecified for the type of (in)formal relation. The noun spelling the addressee undergoes $\mathrm{N}$-to-Voc, and obligatorily checks Voc1 for [2nd] or else it would not have the addressee reading. Note that [2nd ] is also important for the VocP to qualify as an argument of SAP in (4), so this feature is necessarily mapped to the highest Voc head: the item merged at the edge of VocP1 is thus visible to the SA probe. On the other hand, the kinship noun merges directly in Spec, VocP2 and checks [i-p]/ [kinship]. The kinship relation becomes interpretable when the kinship noun and the vocative noun meet in a local Spec-head relation when the vocative $\mathrm{N}$ moves through Voc2. A vocative particle like BRE is optional, as a modifier to the addressee (i.e., Spec, VocP1) and when it occurs, it further details the identity of the addressee and the type of inter-personal relation.

The prediction of this analysis is that reverse vocatives involve head-tohead movement to Voc on an obligatory basis, since the lowest Spec position is occupied by the kinship DP. We test this prediction in (20). First, we must point out that the addressee is by default a name, not a common noun, so our prediction cannot be verified by means of common noun phrases. So, we can construct a DP containing a name, and test its compatibility with reverse vocatives.

$\begin{aligned} \text { (20) a. } & \text { Dănuța mea, vezi ce faci. } \\ & \text { Dănuța my mind.IMP what do.2SG } \\ & \text { 'Dănuța (my girl), mind what you are doing.' } \\ \text { b. } \quad \text { `Dănuța mea mamă, vezi } \quad \text { ce faci. } & \text { Dănuța my mother mind.IMP what do.2SG } \\ \text { c. } \quad \text { Dănuță/ Dănuțo mamă, vezi ce faci. } & \text { Dănuța.VOC mother mind.IMP what do.2SG } \\ & \text { 'Dănuța, mind what you are doing } \\ & \text { (I'm telling you as your mother).' }\end{aligned}$

In (20a), we see a regular VocP that contains a DP in Spec, VocP. We know that the vocative name is a DP because it is modified by a possessive pronoun, which merges only in the DP field. The same DP rules out the reversed vocative in (20b). However, if we delete the possessive pronoun, as in (20c), the reverse vocative is grammatical. The deletion removes the necessity of XP movement.

We may expect cross-linguistic variation within (19) in the same way there is variation within (16). Iovino (2013) illustrates such possibilities for Southern Italian dialects. The main point is that (19) captures the possible finer grained articulation of the VocP field, which can be predictable on the basis of the recursive property of the syntactic structure. 


\section{Language contact}

Our analysis showed how an element like BRE can be useful to discover the underlying structure of vocative phrases. This is a pan-Balkan element that has undoubtedly spread through language contact. However, we have to distinguish between two sub-cases of language contact with regard to vocative phrases: one is a straightforward instance of lexical borrowing (i.e., bre/vre); the other (i.e., the reverse vocative) involves the borrowing of a syntactic pattern.

Importantly, the reverse vocatives do not qualify as a Balkan Sprachbund property, because they exist outside the Balkans. This is the list of languages we know off with reverse vocatives: Arabic dialects, Georgian, Bulgarian, Romanian, the Rromani variety spoken in Romania, and Sicilian varieties. The construction is absent from the other Balkan languages. This distribution indicates that the construction is not originating in the Balkan area, but spread to this area from somewhere else. Furthermore, the languages concerned are at the edges of the Balkan Sprachbund. Since there is no geographical proximity between Bulgaria/Romania and Sicily, it means that the construction originated at a third location and was introduced to both areas, independently. Mladenova (2007), following Beyrer and Kostov (1978), reports that reverse vocatives were already present in Bulgarian at the time of damaskins writing (around the 17th century), so the construction is older than that. Her analysis is that the kinship noun has been grammaticalized out of a PP in Bulgarian and then we can infer that the construction spread to Romanian via the few bilingual pockets at the North of the Danube (MLADENOVA; MLADENOVA 2013). A Bulgarian origin of this construction is, however, unlikely, since, on the one hand, there was no significant Romanian-Bulgarian bilingualism after the 10th century, and on the other hand, the construction would have had to spread throughout the entire Balkan area in order to reach Sicily, and that is not the case.

The alternative explanation we propose is that the reverse vocative originates in Anatolia, since it occurs in bilingualism or multilingualism with Arabic in that area (RIESCHILD, 1998). The construction must have been used there in the Middle Ages, judging by the time it surfaces in Bulgarian and by the time needed for a language contact borrowing to get fixed in the language. The Sicilian borrowing would then follow from bilingualism with Arabic. Georgian may have also had language contact and a bilingual history with Arabic between the 7th - 12th centuries (SUNY, 1994). But how did the construction travel around the Black Sea shore, for such a distance, to Bulgarian? Turkish does not have the construction, so the bilingualism with Turkish cannot explain it. However, at least one dialect of Rromani does - the one spoken in Romania (we had no opportunity to check on other Rromani dialects). Historically, the Rromis have been in Anatolia since the 10th century and, starting from around the 14th century, large groups were being brought to Bulgaria and Romania

Revista Letras,

Curitiba, UFPR, n. 96, pp.334-353,

jul./dez. 2017. ISSN 2236-0999 (versão eletrônica) 
as slaves (GORDON, 1980). Considering the trajectory of the spread, it seems reasonable to consider the Rromani dialect spoken by these groups of slaves as the catalyst for the propagation, since they became necessarily bilingual with Bulgarian and Romanian, respectively. However, this is a question for historical linguists and much more research is needed to verify this hypothesis.

For us, the point of these remarks on the spread of the reverse vocative is that what has been spread is a syntactic structure, namely, the structure in (19), whereas the lexical material that spells it out is different from one language to another. For example, there is variation with respect to what kinship nouns are preferred (e.g., 'wife' in Southern Italian, but not in Romanian), and also in the type of operations that ensure feature checking and valuation for [2nd] and [kinship]. Therefore, unlike BRE, which is a lexical borrowing, the reverse vocative is a pattern borrowing, which entails a situation of long term bilingualism.

\section{References}

$\mathrm{ABOH}, \mathrm{E}$. Topic and focus within $\mathrm{D}^{\star}$. Linguistics in the Netherlands, v. 21, p. $1-12,2004$.

BEYRER, A.; KOSTOV, K. "Umgekehrte Anrede" im Bulgarischen und Rumänischen? Linguistique balkanique, v. 21, n. 4, p. 41-53, 1978.

350 BERNSTEIN, J. English th- Forms. In: KLINGE, A.; MÜLLER, H.H. (Eds.), Essays on Nominal Determination: From Morphology to Discourse Management. Amsterdam: J. Benjamins, 2008a. p. 213-232.

BERNSTEIN, J. Reformulating the Determiner Phrase Analysis. Language and Linguistics Compass, v. 2, n. 6, p. 1246-1270. 2008b.

CINQUE, G. Adverbs and functional heads. A cross-linguistic perspective. New York: Oxford University Press, 1999.

CRISMA, P. L'articolo nella prosa inglese antica e la teoria degli articoli nulli. Ph.D dissertation,

\section{UNIVERSITÀ DEGLI STUDI DI PADOVA, 1997.}

D'HULST, Y.; COENE, M.; TASMOWSKI, L. Romance vocatives and the DP hypothesis. In: CUNITA, A.; LUPU, C; TASMOWSKI, L. (Eds.), Studii de lingvistică şi filologie romanică. Hommages offerts a Sanda Reinheimer Rîpeanu. Bucharest: Editura Universității din Bucureşti. 2007. p. 200-211.

FINK, R. Person in nouns: is the vocative a case? American Journal of Philology, v. 93, n. 1, p. 61-68. 1972. 
FOLLI, R.; SEVDALI, C.; TRUSWELL, R. Introduction. In: FOLLI, R.; SEVDALI, C.; TRUSWELL (Eds.), Syntax and its limits. Oxford: Oxford University Press, 2013. p.1-15.

DEL GOBBO, F. ; POLETTO, C. A Typology of Sentential Particles. Talk at Giornata di Dialettologia, Università di Padua, 20th June 2008.

GIORGI, A. About the Speaker: Towards a syntax of indexicality. Oxford: OUP, 2010.

GIUSTI, G. La sintassi dei determinanti. Padova: Unipress, 1993.

GIUSTI, G. At the left periphery of the Romanian Noun Phrase. In: COENE, M; TASMOWSKI, L. (Eds.), On Space and Time in Language. Cluj: Clusium, 2005. p. 23-49.

GORDON, A. Hearts upon the highway. Scotland: Gordon, 1980.

HAEGEMAN, L.; HILL, V. Vocatives and speech act projections: a case study in West Flemish. In: CARDINALETTI, A.; CINQUE, G.; ENDO, Y. (Eds.), On peripheries. Tokyo: Hituzi Syobo, 2014. p. 207-234.

HARLEY, H.; RITTER, E. Person and number in pronouns: a featuregeometric analysis. Language, v. 78, p. 482-526. 2002.

HILL, V. Vocatives and the pragmatics-syntax interface. Lingua, v. 117, p. 2077-2105. 2007.

HILL, V. Vocatives. Leiden: Brill. 2014.

IOVINO, R. Reverse Vocatives in Romanian and in Central and Southern Italian Varieties. Talk at Workshop on Balkan Romance Contact, Nov 25-27, 2013. University of Venice.

JOSEPH, B. Methodological issues in the history of the Balkan lexicon. The case of Greek vre/re and its relatives. Balkanistica, v. 10, p. 255-277. 1997.

KIDWAI, A. The cartography of phases : facts and inference in Meiteilon. In :DI SCIULLO, A-M.; HILL, V. (Eds.), Edges, heads and projections. Amsterdam : John Benjamins, 2010. p. 233-261.

LONGOBARDI, G. Reference and proper names: a theory of N-movement in syntax and logical form. Linguistic Inquiry, v. 25, n. 4, p. 609-665. 1994.

MIYAGAWA, S. Agreements that occur mainly in main clauses. In: AELBRECHT, L.; HAEGEMAN, L.; NYE, R. (Eds.), Main Clause Phenomena: New Horizons. Amsterdam: John Benjamins, 2012. p. 79-112.

MLADENOVA, O. Definiteness in Bulgarian: Modelling the Processes of Language Change. New York/Berlin: Mouton de Gruyter, 2007.

Revista Letras,

Curitiba, UFPR,

n. 96, pp.334-353,

jul./dez. 2017.

ISSN 2236-0999

(versão eletrônica) 
MLADENOVA, O.; MLADENOVA, D. Transdanubian Electronic Corpus. Supplement to Bulgarian Dialects in Romanian by Maxim Mladenov. 2013. http://www.corpusbdr.info

MUNARO, N.; POLETTO, C. Ways of Clause-typing. Rivista di Grammatica Generativa, v. 27, p. 87-105. 2004.

OYHAR-ABAL, B. Verb agreement with non-arguments: On allocutive agreement. In: HUALDE, J. I.: DE URBINA, J.O. (Eds). Generative Studies in Basque Linguistics. Amsterdam: John Benjamins, 1993. p. 89-114.

POLETTO, C.; ZANUTTINI, R. Sentential Particles and Remnant Movement. In: BENINCÀ, P.; MUNARO, N. (Eds.). Mapping the Left Periphery. New York: Oxford University Press, 2009. p. 201-230.

RIESCHILD, V.R. Lebanese Arabic reverse role vocatives. Anthropological Linguistics, v. 40, n. 4, p. 617-641. 1998.

ROSS, J. R. On declarative sentences. In: JACOBS, R.A.; ROSENBAUM, P.S. (Eds.). Readings in English Transformational Grammar. Washington, DC: Georgetown University Press, 1970. p. 222-272.

SIGURĐSSON, H. Á. The syntax of Person, Tense, and speech features. Italian Journal of Linguistics / Rivista di Linguistica, v. 16, p. 219-251. 2004.

SIGURĐSSON, H. A. The Case of PRO. Natural Language and Linguistic Theory, v. 26, p. 403-450. 2008.

SIGURĐSSON, H. A. Conditions on argument drop. Linguistic Inquiry, v. 42, n. 2, p. 267-304. 2011.

SPEAS, M. Evidentiality, logophoricity and the syntactic representation of pragmatic features. Lingua, v. 144, n. 3, p. 255-276. 2004.

SPEAS, M.; TENNY, C. Configurational properties of point of view roles. In: DI SCIULLO, A.M. (Ed.), Asymmetry in grammar, Amsterdam: John Benjamins, 2003. p. 315-344.

STAVROU, M. About the Vocative Phrase. In: SCHÜRCKS, L.; GIANNAKIDOU, A.; ETXEBERRIA, U. (Eds.). The nominal structure in Slavic and beyond. Berlin: Walter de Gruyter, 2014. p. 299-342.

SUNY, R. G. The Making of the Georgian Nation. Bloomington: Indiana University Press, 1994.

TENNY, C. Evidentiality, experiencers, and the syntax of sentience in Japanese. Journal of East Asian Linguistics, v. 15, p. 245-288. 2006.

TSOULAS, G.; ALEXIADOU, A. On the Grammar of the Greek Particle Re. Ms. 2005. 
V. HiLl Vocatives in the Balkans

WILTSCHKO, M. The universal structure of categories. Cambridge: Cambridge University Press, 2014.

ZANUTTINI, R. Encoding the Addressee in the syntax: Evidence from English imperative subjects. Natural Language and Linguistic Theory v. 26, n. 1, p.185218. 2008.

$\mathrm{ZU}, \mathrm{X}$. An investigation of the structure of $\mathrm{CP}$ and $\mathrm{DP}$ in Jingpo. MA thesis. The Chinese University of Hong Kong. 2011.

Submetido em: 12-01-2017

Aceito em: 14-07-2017 